\title{
PENGARUH KOMPETENSI DAN MOTIVASI TERHADAP KUALITAS PELAYANAN PERIZINAN PADA DINAS PENANAMAN MODAL DAN PELAYANAN TERPADU SATU PINTU KOTA PALEMBANG
}

\author{
Yofitri Heny Wahyuli \\ Dosen Sekolah Tinggi Ilmu Administrasi (STIA) Satya Negara Palembang \\ Email: vivin_khanza@yahoo.com
}

\begin{abstract}
The purpose of this study was to analyze the effect of employee competencies and employee motivation simultaneously or partially on the quality of services at the Investment and Integrated One Top Service Agency of Palembang city. This study uses a quantitative research approach with census strategies. The study population was 25 civil servants. The data used is cross section data collected using a questionnaire. The data analysis technique used is multiple linear regression with $F$ test and $t$ test. The results showed that employee competency and employee motivation simultaneously had a positive effect on the quality of services; employee competence partially has a positive effect on the quality of services; and employee motivation simultaneously has a positive effect on the quality of services Palembang city.
\end{abstract}

Keywords: Competence; Motivation; Service Quality.

\begin{abstract}
ABSTRAK
Tujuan penelitian ini adalah menganalisis pengaruh kompetensi pegawai dan motivasi pegawai secara simultan maupun parsial terhadap kualitas pelayanan perizinan pada Dinas Penanaman Modal dan Pelayanan Terpadu Satu Pintu Kota Palembang. Penelitian ini menggunakan pendekatan penelitian kuantitatif dengan strategi sensus. Populasi penelitian adalah pegawai negeri sipil di lokasi tersebut sebanyak 25 orang dan semuanya dijadikan responden. Data yang digunakan adalah data seksi silang yang dikumpulkan dengan menggunakan kuesioner. Teknik analisis data yang digunakan adalah regresi linear berganda dengan uji $F$ dan uji t. Hasil penelitian menunjukkan bahwa kompetensi pegawai dan motivasi pegawai secara simultan berpengaruh positif terhadap kualitas pelayanan perizinan; kompetensi pegawai secara parsial berpengaruh positif terhadap kualitas pelayanan perizinan; dan motivasi pegawai secara simultan berpengaruh positif terhadap kualitas pelayanan perizinan di Dinas Penanaman Modal dan Pelayanan Terpadu Satu Pintu Kota Palembang.
\end{abstract}

Kata Kunci: Kompetensi; Motivasi; Kualitas pelayanan.

\section{A. PENDAHULUAN}

Kualitas pelayanan perizinan merupakan salah satu bidang perhatian serius administrasi publik dalam dekade terakhir. Produk dari pelayanan perizinan adalah surat izin untuk melaksanakan kegiatan bisnis atau usaha dalam bidang tertentu. Publik menginginkan agar pelayanan perizinan diselenggarakan dengan cara yang berkualitas. Pelayanan perizinan yang berkualitas menekankan kemaslahatan warganegara dan keberpihakan kepada warganegara (Löffler, 2009). Namun, mewujudkan pelayanan perizinan yang berkualitas bukanlah pekerjaan yang mudah karena pelayanan perizinan terkait erat dengan kompetensi dan motivasi aparat pelayanan publik. Untuk memperoleh pelayanan perizinan yang berkualitas, diperlukan aparat yang kompeten dan memiliki motivasi kerja yang tinggi.

Kualitas pelayanan perizinan di sebagian daerah belum sesuai dengan harapan publik, walaupun ada juga daerah yang sudah menyediakan pelayanan perizinan yang berkualitas (Widyastuti, 2014). Padahal pemerintah telah mengadopsi berbagai kebijakan dan instrumen pelaksanaannya guna merealisasikan pelayanan perizinan yang 
berkualitas. Hal ini merupakan tantangan bagi para peneliti administrasi publik untuk memperbanyak analisis empiris tentang kualitas pelayanan perizinan serta faktor-faktor yang mempengaruhinya.

Di Kota Palembang, institusi pelayanan perizinan adalah Dinas Penanaman Modal dan Pelayanan Terpadu Satu Pintu (selanjutnya disebut Dinas PM dan PTSP). Jenis perizinan pada Dinas PM dan PTSP Kota Palembang sebanyak 91 jenis pada 15 sektor pelayanan. Hasil studi awal penulis menunjukkan bahwa kualitas pelayanan perizinan pada Dinas PM dan PTSP Kota Palembang belum mencapai tingkat yang prima sesuai dengan yang diharapkan oleh pengguna layanan. Fenomena pelayanan perizinan yang belum berkualitas prima antara lain fungsi tim kerja verifikasi lapangan yang lamban, kinerja penanganan pengaduan yang rendah, dan belum optimalnya fungsi pelayanan penyuluhan dan konsultasi pada petugas lini depan.

Di sisi yang lain terlihat pula adanya sebagian pegawai yang kurang memahami substansi tugas dan melayani dengan santai. Fenomena pertama, kurang memahami substansi tugas, mencerminkan kurangnya kompetensi, sedangkan fenomena kedua, melayani dengan santai, mencerminkan rendahnya motivasi pegawai. Belum tersedia penjelasan teoritis perihal pengaruh simultan dan parsial dari kompetensi dan motivasi pegawai terhadap kualitas pelayanan perizinan pada Dinas PM dan PTSP Kota Palembang. Pengetahuan empiris tersebut diperlukan untuk membantu mendekatkan kesenjangan literatur pelayanan perizinan dalam administrasi publik dan dapat menjadi acuan bagi pemerintah daerah untuk mendesain program peningkatan kualitas pelayanan perizinan. Artikel ini berusaha untuk menyediakan pengetahuan analitik tentang pengaruh kompetensi dan motivasi pegawai terhadap kualitas pelayanan perizinan.

Kompetensi adalah salah satu konsep pokok dalam administrasi publik khususnya dalam administrasi kepegawaian public (Aravik, 2017). Konsep ini dipopulerkan oleh McClelland pada awal 1970-an. Sebelumnya, istilah yang digunakan untuk menggambarkan fenomena yang dimaksudkan adalah keterampilan. Mc Clelland mengajukan konsep kompetensi sebagai pengganti dari konsep keterampilan. McClelland menyatakan bahwa kompetensi adalah prediktor yang signifikan dari kinerja karyawan (Vazirani, 2010). Dengan teorinya tersebut, Mc Clelland dikenal sebagai bapak dari gerakan kompetensi.

Kompetensi diartikan sebagai suatu kapabilitas yang berbasis pada kehendak yang kuat (Boyatzis, 2008). Definisi operasional dari kompetensi adalah seperangkat kapabilitas yang terintegrasi; yang terdiri dari kluster pengetahuan, keterampilan dan sikap; yang bersifat kondisional bagi kinerja yang efektif; dalam suatu konteks, profesi, organisasi, jabatan, peran dan situasi tertentu (Mulder, 2014). Untuk dapat memahami kompetensi pegawai secara komprehensif, para analis menggunakan model gunung es kompetensi dari Spencer \& Spencer. Sisi bagian atas permukaan gunung es kompetensi adalah pengetahuan dan keterampilan, seringkali disebut kompetensi teknis, sedangkan sisi bagian bawah permukaan air kompetensi adalah citra diri, watak atau sifat, dan motif, seringkali disebut kompetensi keperilakuan (Omisore, 2013).

Motivasi secara sederhana berarti hal-hal yang mendorong atau menggerakkan seseorang untuk melakukan atau tidak melakukan sesuatu perilaku (Lai, 2011). Seseorang memiliki motivasi artinya orang tersebut tergerak untuk melakukan sesuatu, sebaliknya seseorang yang tidak merasakan adanya daya dorong atau inspirasi untuk bertindak dikarakterisasikan sebagai tidak memiliki motivasi. Motivasi, menurut Ryan, Richard M., and Deci, (2000), dapat muncul dari dalam diri karyawan tetapi dapat pula muncul dari aktivitas manajemen sumberdaya manusia.

Penjelasan teoritis tentang motivasi karyawan seringkali diatribusikan kepada Herzberg. Teorinya yang sangat popular, teori motivasi dua faktor, mengajukan bahwa dalam pekerjaan ada serangkaian kondisi ekstrinsik dan kondisi intrinsik. Kondisi ekstrinsik dapat menyebabkan rasa tidak puas apabila tidak tersedia, akan tetapi kalaupun kondisi ini tersedia tidak memotivasi karyawan. Kondisi intrinsik, di lain pihak, apabilaterdapat dalam pekerjaan, akan menggerakkan tingkat motivasi yang kuat yang dapat menghasilkan 
prestasi kerja yang baik. Asumsi dasar teori dua faktor Herzberg adalah, jika manajer ingin meningkatkan kepuasan jabatan dan sekaligus kinerja jabatan dari karyawan, maka manajer perlu berfokus pada faktor-faktor intrinsik. Faktor intrinsik dalam teori motivasi duafaktor Herzberg meliputi prestasi, pengakuan, kemajuan, pekerjaan itu sendiri dan kemungkinan berkembang (Gibson, James L., John M. Ivancevich, James H. Donnelly, Jr., 2012).

Perizinan menunjuk pada proses pemberian izin. Izin adalah suatu persetujuan dari pemerintah berdasarkan undang-undang atau peraturan (Sutedi, 2011). Istilah izin ini seringkali disejajarkan dengan dispensasi, lisensi, dan konsesi. Perizinan adalah pemberian legalitas kepada seseorang atau pelaku usaha/ kegiatan tertentu, baik dalam bentuk izin maupun tanda daftar usaha. Perizinan, menurut Sutedi, (2011)., mempunyai dua fungsi, yakni fungsi sebagai penertib dan sebagai pengatur. Perizinan sebagai fungsi penertib dimaksudkan agar setiap bentuk kegiatan masyarakat tidak bertentangan satu dengan yang lainnya, sehingga ketertiban dalam setiap segi kehidupan masyarakat dapat terwujud.

Pelayanan perizinan merupakan salah satu bentuk pelayanan publik. Definisi pelayanan publik menurut Thoha, (1991) adalah usaha yang dilakukan oleh seseorang/kelompok orang atau institusi tertentu untuk memberikan bantuan dan kemudahan kepada masyarakat dalam rangka mencapai suatu tujuan tertentu. Kualitas pelayanan berarti totalitas dari tampilan dan karakteristik pelayanan yang berhubungan dengan kemampuannya untuk memenuhi kebutuhan yang dicari oleh penerima layanan. Kualitas pelayanan publik di pemerintah daerah, menurut Löffler, (2009), harus berfokus pada kemaslahatan warganegara dan berpihak kepada warganegara, dengan indikator: mudah diakses, disediakan dengan segera, responsif terhadap kebutuhan yang layak dari warganegara, dikomunikasikan dengan jelas dan konsisten, dan disediakan dalam cara yang efektif biaya.
Kompetensi dan motivasi mempunyai hubungan logis dengan kualitas pelayanan publik, termasuk pelayanan perizinan. Banga, (2018) mengemukakan bahwa kompetensi dan motivasi adalah topik penting dalam pengaturan terhadap personalia dan perwujudan kepegawaian yang merupakan komponen administrasi publik. Ruki \& Rukmana, (2016) mengatakan bahwa kompetensi pegawai berpengaruh positif terhadap kualitas pelayanan publik. Tamami, (2016) mengemukakan bahwa motivasi pegawai berpengaruh positif terhadap kualitas pelayanan. Rukmana, (2016) mengatakan bahwamotivasi dan kompetensi keduanya berpengaruh terhadap kualitas pelayanan. Merujuk literatur teoritis dan empiris di atas, penelitian ini memprediksikan bahwa:

1) Kompetensi dan motivasi pegawai secara simultan berpengaruh terhadap kualitas pelayanan perizinan.

2) Kompetensi pegawai secara parsial berpengaruh terhadap kualitas pelayanan perizinan.

3) Motivasi pegawai secara parsial berpengaruh terhadap kualitas pelayanan perizinan.

\section{B. METODE PENELITIAN}

Penelitian ini berlokasi pada Dinas PM dan PTSP Kota Palembang. Populasi penelitian ini adalah seluruh pegawai pada Dinas PM dan PTSP Kabupaten Konawe Utara sebanyak 25 orang yang diteliti seluruhnya secara langsung. Desain penelitian ini adalah penelitian asosiatif. Pendekatan yang digunakan adalah pendekatan penelitian kuantitatif di mana asosiasi antar variabel didasarkan pada teoriteori yang relevan, diukur dengan angkaangka, dan dianalisis dengan prosedur statistik. Dalam model penelitian ini, kompetensi pegawai dan motivasi pegawai menjadi variabel bebas sedangkan kualitas pelayanan perizinan adalah variabel terikat. Kompetensi pegawai diukur dengan 10 item, motivasi pegawai diukur dengan 11 item, sedangkan kualitas pelayanan perizinan diukur dengan 10 item.

Seluruh item mengikuti konstruksi skala Likert dengan 5 skala, yakni: Tidak Setuju 
(skor 1), Kurang Setuju (skor 2), Agak Setuju (skor 3), Setuju (skor 4), dan Sangat Setuju (skor 5). Kuesioner terlebih dahulu diuji validitasnya dengan Pearson product moment correlation, dan reliabilitasnya dengan Cronbach's Alpha pada IBM-SPSS Statistics versi 24.0. Hasil pengujian menunjukkan bahwa seluruh item adalah valid dan reliabel sehingga sehingga cocok diterapkan untuk mengukur kompetensi pegawai, motivasi pegawai dan kualitas pelayanan perizinan. Data hasil kuesioner diolah dengan menggunakan prosedur statistik pada IBMSPSS Statistics versi 24.0. Hipotesis tentang pengaruh simultan kompetensi dan motivasi terhadap kualitas pelayanan perizinan diuji dengan uji $\mathrm{F}$, sedangkan hipotesis tentang pengaruh parsial dari variabel-variabel tersebut diuji dengan uji t pada regresi linear berganda.

\section{HASIL DAN PEMBAHASAN}

Secara statistik, variabel kompetensi pegawai mempunyai rata-rata skor sebesar 3,99 atau $79,8 \%$ dari skor ideal. Variabel kompetensi pegawai tergolong baik namunbelum pada tingkat yang optimal. Motivasi pegawai mempunyai rata-rata skor sebesar 3,98 atau $79,6 \%$ dari skor ideal. Motivasi pegawai juga tergolong baik, namun belum pada tingkat yang optimal. Kualitas pelayanan perizinan mempunyai rerata skor sebesar 4,02 atau $80,3 \%$ dari skor ideal. Kualitas pelayanan perizinan secara umum tergolong baik, namun belum pada tingkat yang optimal. Pada ketiga variabel tersebut masih ada item-item yang secara empiris belum tersedia secara paling optimal sehingga belum memperoleh penilaian yang maksimum dari responden penelitian.

Hipotesis pertama memprediksikan pengaruh positif dari kompetensi dan motivasi pegawai secara simultan terhadap kualitas pelayanan perizinan. Hasil statistik menunjukkan konstanta $(\alpha)=3,370$; Fhitung $=$ 32,$115 ; \beta 1=0,379 ;$ dan $\beta 2=0,230$. Nilai Fhitung 32,115 dengan probabilitas $=0,000$ mengindikasikan bahwa kedua variabel secara simultan berpengaruh terhadap kualitas pelayanan perizinan. Hipotesis nol tentang pengaruh simultan ditolak. Nilai $\mathrm{R}$ square sebesar positif 0,906 menunjukkan variasivariasi dalam nilai kompetensi dan motivasi pegawai dapat menjelaskan sebesar 90,6 persen dari variasi kualitas pelayanan perizinan. Nilai $\mathrm{R}$ square mengindikasikan suatu good fit sehingga baik digunakan untuk melakukan estimasi dengan model regresi. Adapun model regresi yang diperoleh dari data penelitian ini adalah:

$$
\mathrm{Y}=-3,370+0,379(\beta 1)+0,230(\beta 2)
$$

Hipotesis kedua memprediksikan pengaruh positif kompetensi pegawai terhadap kualitas pelayanan perizinan. Analisis data menghasilkan nilai t hitung sebesar 2,742 dan signifikan pada $\alpha .012$ sedangkan $\beta(1)$ sebesar 0,379 . Nilai $t$ hitung variabel kompetensi pegawai sebesar 2,741 adalah lebih besar dari $\mathrm{t}$ tabel $(2,741>1,672)$ yang secara statistik menunjukkan bahwa variabel kompetensi pegawai mempengaruhi variabel kualitas pelayanan perizinan. Lagi pula $\beta 1$ tidak sama dengan nol $(0,379 \neq 0)$ sehingga hipotesis nol ditolak. Model regresi yang diperoleh dari data penelitian ini adalah:

$$
\mathrm{Y}=-3,370+0,379(\beta 1)
$$

Hipotesis ketiga memprediksikan pengaruh positif motivasi pegawai terhadap kualitas pelayanan perizinan. Analisis data menghasilkan nilai t hitung sebesar 1,992 dan signifikan pada $\alpha .059$ sedangkan $\beta(\mathrm{Mt})$ sebesar 0,230 . Nilai thitung variabel motivasi pegawai sebesar 1,992 adalah lebih besar dari t tabel $(1,992>1,672)$ yang secara statistik menunjukkan bahwa variabel motivasi pegawai mempengaruhi kualitas pelayanan perizinan. Lagi pula, $\beta 3$ tidak sama dengan nol $(0,230 \neq 0)$ sehingga hipotesis nol ditolak. Model regresi yang diperoleh dari data penelitian ini adalah:

$$
\mathrm{Y}=-3,370+0,230(\beta 3)
$$

Dalam model parsial di atas, pengaruh kompetensi pegawai adalah sebesar 0,379. Diprediksikan bahwa setiap satuan kenaikan dalam kompetensi pegawai adalah berasosiasi dengan suatu kenaikan sebesar 0,379 unit dalam kualitas pelayanan perizinan. Pengaruh motivasi pegawai adalah sebesar 0,233. Diprediksikan bahwa setiap satuan kenaikan dalam motivasi pegawai adalah berasosiasi dengan suatu kenaikan sebesar 0,230 unit dalam kualitas pelayanan perizinan.

Hasil statistik deskriptif menunjukkan bahwa semua variabel berada pada kategori baik, namun belum pada tingkat yang optimal. 
Setiap variabel mempunyai item yang berada di bawah kategori baik. Hasil pengujian menunjukkan bahwa kedua variabel secara simultan berpengaruh terhadap kualitas pelayanan perizinan. Hubungan antara kompetensi dan motivasi pegawai dengan kualitas pelayanan perizinan adalah positif dan signifikan yang dimaknai bahwa variasivariasi dalam nilai kompetensi dan motivasi pegawai dapat menjelaskan sebagian besar dari variasi kualitas pelayanan perizinan. Temuan penelitian ini menyediakan dukungan empiris untuk teori-teori yang telah diuraikan sebelumnya. Implikasi dari temuan ini adalah jika pimpinan menghendaki kualitas pelayanan perizinan yang lebih baik lagi maka kompetensi dan motivasi pegawai perlu ditingkatkan kondisinya agar menjadi lebih baik dari yang telah ada sekarang. Usaha perbaikan terhadap kompetensi dan motivasi pegawai sebaiknya dilakukan secara sinergis dan terintegrasi.

Hasil pengujian juga menunjukkan bahwa kompetensi pegawai secara parsial berpengaruh terhadap kualitas pelayanan. Hubungan antara kompetensi pegawai dengan kualitas pelayanan perizinan adalah positif dan signifikan. Hasil analisis menunjukkan bahwa variasi dalam nilai kompetensi pegawai dapat menjelaskan variasi kualitas pelayanan perizinan. Temuan penelitian ini menyediakan dukungan empiris untuk teori kompetensi McClelland, maupun hasil studi Ruki \& Rukmana, (2016). Namun, beberapa sisi kelemahan kompetensi pegawai yang ditemukan di lokasi penelitian ini perlu dibenahi agar pegawai dapat atau mampu menangani tantangantantangan pelayanan perizinan dengan cara-cara yang tepat.

Hasil pengujian menunjukkan pula bahwa motivasi pegawai berpengaruh positif dan signifikan terhadap kualitas pelayanan perizinan. Temuan penelitian ini menyediakan dukungan empiris untuk teori motivasi Herzberg dalam Gibson, James L., John M. Ivancevich, James H. Donnelly, Jr., (2012). Namun, temuan penelitian ini menunjukkan adanya anomali bagi teori motivasi Herzberg. Teori motivasi Herzberg memprediksikan bahwa motivator hanya terdapat pada kondisi intrinsik, tidak terdapat pada kondisi ekstrinsik pekerjaan. Dengan demikian, proposisiteori motivasi Herzberg yang berfokus pada faktor intrinsik tidak sepenuhnya dapat menjelaskan kualitas pelayanan perizinan karena adanya respek terhadap motivasi material (motivasi ekstrinsik) sebagaimana ditemukan juga pada konteks yang lain oleh (Makki, A. \& Abid, 2017) \& Met, M.; Ali, I.; and Ali, (2017)

\section{KESIMPULAN}

Kompetensi dan motivasi pegawai secara simultan berpengaruh terhadap kualitas pelayanan perizinan di Dinas PM dan PTSP Kota Palembang. Secara parsial, kompetensi dan motivasi pegawai juga berpengaruh positif dan signifikan terhadap kualitas pelayanan perizinan. Di antara kedua variabel tersebut, kompetensi pegawai lebih kuat pengaruhnya terhadap kualitas pelayanan perizinan dibandingkan dengan motivasi pegawai. Kompetensi, motivasi pegawai dan kualitas pelayanan perizinan di konteks tersebut masih perlu ditingkatkan melalui strategi yang sinergis dan terintegrasi.

\section{DaftarPustaka}

Aravik, F. Z. \& H. (2017). Manajemen SDM Berbasis SDM. CV. RWTC Success.

Banga, W. (2018). Kajian Administrasi Publik Kontemporer Konsep, Teori dan Aplikasi. Edisi revisi. Penerbit Gava Media.

Boyatzis, R. E. (2008). Competencies in the 21st Century. Journal of Management Development, 27(1), 5-12.

Gibson, James L., John M. Ivancevich, James H. Donnelly, Jr., and R. K. (2012). Organizations: Behavior, Structure, Processes. Fourteenth Edition. McGrawHill.

Lai, E. R. (2011). Motivation: A Literature Review. Pearson's Research Reports. http://www.pearsonassessments.com/rese arch. 
Löffler, E. (2009). Improving the Quality of Public Services: Putting The Citizens at the Centre of Administrative Action. Support for Improvement in Governance and Management (SIGMA).

Makki, A. \& Abid, M. (2017). Influence of Intrinsic and Extrinsic Motivation on Employee's Task Performance. Studies in Asian Social Science, 4(1), 38-43.

Met, M.; Ali, I.; and Ali, J. (2017). Monetary Reward and Job Satisfaction Influence Employee Performance? Evidence from Malaysia. European Journal of Business and Social Sciences, 3(11), $184-200$.

Mulder, M. (2014). Conceptions of Professional Competence. In: S. Billett, C. Harteis, H. Gruber (Eds. In International Handbook of Research in Professional and Practicebased Learning. Springer.

Omisore, B. O. (2013). Strategies to Improve the Competence of Public Service Officials in Nigeria. Journal of Public Administration and Governance, 3(4), 15-30.

Rukmana, R. (2016). Kerja Dan Kompetensi Terhadap Kinerja Pegawai Serta Implikasinya pada Kualitas Perencanaan Pembangunan. Kontigensi, 4(1), 57 - 75.

Ryan, Richard M., and Deci, E. L. (2000). Intrinsic and Extrinsic Motivations: Classic Definitions and New Directions. Contemporary Educational Psychology, 5(1), 54-67.

Sutedi, A. (2011). Hukum Perizinan Dalam Sektor Pelayanan Publik. Sinar Grafika.

Tamami, S. (2016). Pengaruh Gaya Kepemimpinan dan Motivasi Terhadap Kualitas Pelayanan dan Kinerja Pegawai (Studi Kasus Sekretariat DPRD Kota Batam.

Thoha, M. (1991). Perspektif Perilaku Birokrasi. Rajawali Press.
Vazirani, N. (2010). Competencies and Competency Model-A Brief overview of its Development and Application. SIES Journal of Management, 7(1), 121-131.

Widyastuti, B. (2014). Analisis Kualitas Pelayanan Perizinan Investasi di UPT Pelayanan Perizinan Terpadu (P2T) Provinsi dalam Meningkatkan Investasi di Jawa Timur. Kebijakan Dan Manajemen Publik, 1(1). 